\title{
RESEARCH IN SPORT \\ PHYSICAI ACI \\ Exercise is more effective than metformin to improve health related quality of life and mood states in older adults with type 2 diabetes
}

Autor(es): $\quad$ Baptista, Liliana Carina Pereira; Martins, Raúl A.

Publicado por: Imprensa da Universidade de Coimbra

URL persistente:

URI:http://hdl.handle.net/10316.2/44145

DOI:

DOI:https://doi.org/10.14195/2182-7087_ex2018_82

Accessed : $\quad$ 26-Apr-2023 09:56:50

A navegação consulta e descarregamento dos títulos inseridos nas Bibliotecas Digitais UC Digitalis, UC Pombalina e UC Impactum, pressupõem a aceitação plena e sem reservas dos Termos e Condições de Uso destas Bibliotecas Digitais, disponíveis em https://digitalis.uc.pt/pt-pt/termos.

Conforme exposto nos referidos Termos e Condições de Uso, o descarregamento de títulos de acesso restrito requer uma licença válida de autorização devendo o utilizador aceder ao(s) documento(s) a partir de um endereço de IP da instituição detentora da supramencionada licença.

Ao utilizador é apenas permitido o descarregamento para uso pessoal, pelo que o emprego do(s) título(s) descarregado(s) para outro fim, designadamente comercial, carece de autorização do respetivo autor ou editor da obra.

Na medida em que todas as obras da UC Digitalis se encontram protegidas pelo Código do Direito de Autor e Direitos Conexos e demais legislação aplicável, toda a cópia, parcial ou total, deste documento, nos casos em que é legalmente admitida, deverá conter ou fazer-se acompanhar por este aviso. 


\section{ANNALS OF RESEARCH IN SPORT AND PHYSICAL ACTIVITY}




\title{
EXERCISE IS MORE EFFECTIVE THAN METFORMIN TO IMPROVE HEALTH RELATED QUALITY OF LIFE AND MOOD STATES IN OLDER ADULTS WITH TYPE 2 DIABETES
}

\author{
Liliana Carina Pereira Baptista'; Raúl A. Martins
}

KEYWORDS: diabetes, exercise, metformin, mood states, quality of life, older adults.

\section{INTRODUCTION}

Type 2 diabetes (T2D) is a high-impact complex multi-factorial disease that imposes a life-long physical and psychological burden ${ }^{(1)}$, particularly in older adults ${ }^{(2)}$ due to the added effect of co-morbidities, pharmacological treatment, heterogeneous functional status, low exercise training and frequently disruptive negative effects such as restlessness, distress, anxiety, depression and dementia(2,3) reducing the efficacy of T2D management and quality of life $(\mathrm{QoL})^{(4)}$. Furthermore, while the prevalence of mental health problems in older adults with T2D exceeds values found in the general population ${ }^{(4)}$, previously inconsistent results, highlight the need to promote the appropriate strategies to improve the mental component of QoL.Therefore, the aim of this study is to analyze the effect of three types of treatment:

i) exercise training with multicomponent exercise (E); ii) pharmacologic treatment with oral hypoglycemic drug - metformin (M); and iii) a combined therapy - exercise and metformin (MEX) on health related quality of life (HRQoL) and mood states in older adults with type 2 diabetes (T2D) with comorbidity in an early stage of

\section{METHODS}

This un-randomized longitudinal cohort study included 284 T2D older adults (> 60 years) that underwent one of 3 conditions: i) $E(n=59)$ trained three times/week; ii) $M(n$

1 Universidade de Coimbra- Faculdade de Ciências do Desporto e Educação Física.

Email: libaptista10@hotmail.com 
= 30) used $850 \mathrm{mg}$ of metformin twice daily; and iii) MEX ( $\mathrm{n}=195)$ combined exercise and metformin. Participants completed baseline, and 2-year follow-up evaluations including the Short Form Health Survey 36, Profile of Mood States - Short Form, the health history questionnaires, anthropometric and blood biochemistry

\section{RESULTS}

After the 24-months intervention, E and MEX revealed improved mood states, with large effect size on the vigor domain, and moderate effect size in the anger, and total mood disturbance domains, in comparison with the $\mathrm{M}$ group. The $\mathrm{E}$ and MEX groups perceived better physical and mental HRQoL than the M group. Contrarily, the M group unchanged HRQoL domains ( $P>0.05$ ).

\section{CONCLUSIONS}

Metformin had no significant effect on self-referred HRQoL in T2D participants aged above 60 years, in an early stage of the disease. The $E$ and MEX therapies were the most effective to improve mood states, and HRQoL in older adults with T2D.

\section{REFERENCES}

1. Aschner, P. et al., 2014. Global guideline for type 2 diabetes. Diabetes Research and Clinical Practice, $104^{(1)}$, pp.1-52.

2. Gadsby, R., 2014. Diabetes care for older people resident in care homes., 16 ${ }^{(5)}$, pp.259-267.

3. Abdelhafiz, A.H. \& Sinclair, A.J., 2015. Diabetes in the elderly. Medicine (United Kingdom), 43 ${ }^{(1)}$, pp.48-50.

4. American Diabetes Association, 2016. Standards of Medical Care in Diabetes - 2016. Diabetes Care, 39(1), pp.S1-S112. 